\title{
Some Viral Sero-Markers of Patients with Abnormally Raised Total Bile Acid Receiving Treatments in Herbal/Traditional Homes of Some Rural Communities in Nigeria
}

\author{
Mathew Folaranmi OLANIYAN* \\ Department of Medical Laboratory Science, Achievers University Owo -Nigeria \\ *Corresponding author: olaniyanmat@yahoo.com
}

Received August 27, 2014; Revised September 23, 2014; Accepted September 27, 2014

\begin{abstract}
Background to the Study: Blind therapeutic management is a common feature of the traditional management of clinical cases that may obscure immunochemical and biochemical abnormalities such as viral infections and abnormally raised total bile acid (TBA) which may make treatments unsuccessful. Aim and Objective: This work was designed to determine some viral markers of patients with abnormally raised Total Bile Acid receiving treatments in herbal/traditional homes of some rural communities in Nigeria. Materials and Method: Fifty one (51(25.1\%)) of 203 patients aged 21-52 years in Saki-East, Saki-West and ATISBO with abnormally raised total bile acid under going treatment in 15 herbal homes of Saki-East, Saki-West and ATISBO Local Government areas at the Northern part of Oyo state - Nigeria between January and June, 2014 were studied. Thirty two (32(21.3\%)) out one hundred and fifty (150) age-matched patients with abnormally raised TBA visiting five (5) orthodox hospitals were also studied within the same period. 139(92.7\%) with normal TBA out of 150 apparently healthy individuals aged 20-55 years initially selected were studied as normal control subjects. Immuno assays were carried out on the subjects by Immunoblotting and ELIZA while fasting plasma TBA was estimated in the subjects biochemically. Results: There was a lower incidence of positive 6.3\%(2)ant-HIV, 15.6\%(5) anti-HCV antibodies and $25 \%(8)$ HBsAg in patients receiving treatment in orthodox hospitals with a mean plasma TBA of $16 \pm 2.0$ $\mu \mathrm{mol} / \mathrm{L}$ than patients receiving treatment in Herbal homes $7.8 \%(4)$ positive anti-HIV, 17.6\%(9) anti-HCV and $31.4 \%(16) \mathrm{HBsAg}$ obtained in with a mean plasma TBA of $18 \pm 3.2 \mu \mathrm{mol} / \mathrm{L}$. There was also a lower prevalence of positive 3.6\%(5) anti-HIV, 4.3\%(6) anti-HCV and 7.2\%(10) HBsAg with a plasma TBA of $6.5 \pm 0.3 \mu \mathrm{mol} / \mathrm{L}$ in the normal control subjects than the results obtained from the patients receiving treatments from both orthodox and traditional/herbal homes.. The immunochemical status of the subjects also revealed evidence of viral co-infections as $2 \%(1)$ anti-HIV + anti-HCV in patients receiving treatments in herbal homes, 3.1\%(1) anti-HIV + HBsAg in patients receiving treatments in orthodox hospitals with a mean plasma TBA of $16 \pm 2.0 \mu \mathrm{mol} / \mathrm{L}$ and 5.9\%(3) anti-HIV + HBsAg in patients receiving treatments in herbal homes with a mean plasma TBA of $18 \pm 3.2 \mu \mathrm{mol} / \mathrm{L}$. There was a significantly higher difference in the mean plasma value of TBA and the prevalence of the viral markers including coinfections in the patients receiving treatment in orthodox hospitals and in the patients receiving treatments in herbal homes than the results obtained from the normal control with $\mathrm{p}<0.05$. There was also a significantly higher prevalence of the viral markers including coinfections in the patients of herbal homes than the resulusts obtained in the patients of orthodox hospitals and the normal control subjects ( $p<0.05$ ). The frequency of the abnormally raised TBA, of the patients visiting herbal homes, orthodox hospitals and that of the apparently healthy individuals was 51(25.1\%)), 32(21.3\%) and 11(7.3\%) respectively. Conclusion: The incidence of positive HBsAg, anti-HIV, antiHCV antibodies increases with increase in Total Bile Acids considering the mean concentration of the parameter and the pattern of the viral markers in the subjects and are more prevalent in patients receiving treatments from herbal homes than those attending orthodox hospitals and the control subjects. Evaluation of Viral markers of patients with abnormally raised Total Bile Acid is recommended for effective management of this biochemical abnormality in herbal homes.
\end{abstract}

Keywords: viral markers, patients, abnormally raised Total Bile acid, treatments, herbal/traditional homes, rural communities, Nigeria

Cite This Article: Mathew Folaranmi OLANIYAN, "Some Viral Sero-Markers of Patients with Abnormally Raised Total Bile Acid Receiving Treatments in Herbal/Traditional Homes of Some Rural Communities in Nigeria." American Journal of Medical and Biological Research, vol. 2, no. 4 (2014): 91-96. doi: 10.12691/ajmbr-2-4-2. 


\section{Introduction}

In recent times, there seems to be an increase in popularity of herbal medicine, and a serious rivalry between herbal and orthodox medicines. More people are now beginning to resort more to herbal medication at the expense of the orthodox. [1]. World Health Organization (WHO) have recognized the role of herbal traditional medicinal practice in primary health management due to the observation that $80 \%$ of the rural communities consult traditional healers before they go for the orthodox medical services. The traditional herbal practice remains familiar and attritional, thus least developed and hence the patients do not get the best values for their input in the services [2].

Medicinal plants have played a key role in the world health care with about $80 \%$ of Africans depending on phyto-medicine which has shown a wide range of uses in the treatment of diseases, especially priority diseases of Africa such as HIV/AIDS, malaria, sickle cell anaemia, diabetes and hypertension. The usage of plants, plants extracts or plant-derived pure chemicals to treat disease in Nigeria become a therapeutic modality which has stood the test of time. Today, several pharmacological classes of drugs include a natural product prototype [3].

In Nigeria, the majority of citizens still uses medicinal plants and visit traditional medicine practitioners for their health care needs [4]. Although Western medicine is successful in developed countries, it doesn't have the same positive impact in many of the underdeveloped African countries. Though Western practices can make an impact in health care practices, in certain areas such as in the spread of various diseases, it cannot integrate wholly into the culture and society. This makes the traditional African practitioners a vital part of their health care system. There are many reasons why the Western medical system does not work in Africa. Hospitals and medical facilities are difficult for many Africans to get to. With vast areas of land and poor road and transportation systems, many native Africans have to travel immense distances on foot to reach help [5]. Once they arrive they are often required to wait in line for up to 8 hours, especially in urban areas, as the lack of clinics and resources cause over-crowding. Patients are often not told the cause of their illness or much information about it all, so they have no way to prevent or prepare for it. The herbal doctors argue that the orthodox drugs are chemicals(not natural to the body system) and so very much harmful [6].

Hepatitis B virus (HBV) and hepatitis C virus (HCV) infections account for a substantial proportion of liver diseases worldwide. These viruses are responsible for liver damages ranging from minor disorders to liver cirrhosis and hepatocellular carcinoma (HCC). Approximately 7\% of the world's population (350 million people) are infected with HBV and 3\% (170 million people) with HCV. HIV infect all cells including the hepatocytes and could cause tissue and cell destruction but causes liver disorders when there is coinfection with hepatotrophic virus or when the patient is undergoing chemotherapy such as the administration of retroviral drugs[7].

The liver removes bile acids effectively from the portal circulation because of the presence of bile acid transporters on the sinusoidal membrane of hepatocytes.
The high extraction efficiency (first-pass clearance is 75$90 \%$ ) is the reason for low peripheral blood levels of total bile acids (2-10 mmole/L) compared with portal concentrations of bile acids (60-80 mmole/L). Any decrease in the extraction efficiency caused by a decrease in the hepatic blood flow, and/or hepatocellular damage, or any compromises of liver function will result in increases of serum levels of total bile acids. Serum or plasma TBA levels are sensitive indicators of liver function in all species, reflecting both hepatic synthesis, secretion, and re-absorptive functions. Therefore, testing for serum TBA will help to detect liver functional changes before the formation of more advanced clinical signs of illness such as icterus.[8]. The measurement of bile acids in serum is a sensitive indicator of liver function. Fasting serum total bile acid can be used in the diagnosis and prognosis of liver disease. Levels rise in many liver diseases, for example hepatitis and liver sclerosis [8]. Abnormal levels in fasting patients or immediately after a meal can be used to detect liver disease and damage, impaired liver function, intestinal dysfunction and perhaps a gall bladder blockage. Total bile acid measurement may detect some forms of liver disease earlier than standard liver tests because bile acids levels correspond to liver function, rather than liver damage [9].

\section{Materials and Methods}

\subsection{Materials}

\subsubsection{Study Area}

The study was carried out in Saki-East, Saki-West and ATISBO Local government area of Oyo state- Nigeria. The Local Government areas constitute a Federal constituency and majorly rural communities located at Northern part of Oyo state in Nigeria. They share borders with the Republic of Benin, Kwara state-Nigeria, Oorelope, Itesiwaju Local Government areas of Oyo state in Nigeria.

\subsubsection{Study Population}

Fifty one (51(25.1\%)) of 203 patients aged 21-52 years in Saki-East, Saki-West and ATISBO with abnormally raised Total Bile Acid undergoing treatment in 15 herbal homes of Saki-East, Saki-West and ATISBO Local Government areas at the Northern part of Oyo state Nigeria between January and June, 2014 were studied. Thirty two (32(21.3\%)) out one hundred and fifty (150) age-matched patients with abnormally raised TBA visiting five (5) orthodox hospitals were also studied within the same period. 139(92.7\%) with normal TBA out of 150 apparently healthy individuals aged 20-55 years initially selected were studied as normal control subjects.

\subsection{Sample Size}

All 51(25.1\%) patients aged 21-52 years with abnormally raised Total Bile Acid that visited 15 herbal homes in Saki-East, Saki-West and ATISBO Local Government areas at the Northern part of Oyo state Nigeria between January and June, 2014 and Thirty two 32(21.3\%) age-matched patients with abnormally raised TBA that visited five (5) orthodox hospitals in the three 
local government areas were also studied within the same period. 139(92.7\%) with normal TBA out of 150 apparently healthy individuals aged 20-55 years initially selected were studied as normal control subjects.

\subsection{Case Selection Procedure/s}

\subsubsection{Inclusion Criteria}

Anicteric patients with abnormally raised TBA were included as patients from both Traditional homes and Orthodox hospitals. Anicteric patients with normal TBA were studied as normal control subjects.

\subsubsection{Exclusion Criteria}

1. Icteric patients with abnormal TBA visiting the traditional and orthodox hospitals were excluded from the study. Anicteric patients with normal plasma TBA receiving treatments at the traditional homes and Orthodox hospitals were not included as test subjects.

\subsubsection{Blood Sample}

Five (5) milliliter of blood was collected into lithiumheparinized bottle from each of the test and control subjects, for HIV, HBsAg, anti-HCV, and Total Bile Acids tests.

\subsection{Methods}

a. Total Bile Acids measurement of bile acids in serum is a sensitive indicator of liver function. It is a fifth Generation biochemical assay. Estimation of Total Bile Acids was carried out on the plasma samples of the subjects using Randox reagent kit. The manufacturer's instruction was strictly followed.

Principle: Bile acids are oxidised by 3- $\alpha$ hydroxysteroid dehydrogenase with the subsequent reduction of ThioNAD to Thio-NADH. The oxidised bile acids are reduced by thesame enzyme with the subsequent oxidation of $\mathrm{NADH}$ toNAD. The rate of formation of Thio-NADH is determinedby measuring the specific absorbance change at 405 nm.(Abreviations: NADH, NAD, Thio-NADH, ThioNAD).

b. Screening for HIV Antibodies HIV screening were carried out using Immuno chromatographic kit (ChembioHIV 1 and 2 STAT-PAK). Positive samples were further confirmed by Western blot/Immunoblotting using Immunoetics Qualicode TM HIV 1 and 2 kit.

c. Screening for HbsAg by Enzyme- Linked Immunosorbent Assay (ELISA) The ELISA kit from BIORAD Monolisa HBsAg ULTRA EIA92430, France was used. ELISA was done according to the manufactures instruction.

d. Screening for HCV Antibody by ELISA ELISA kit from DIA PRO Diagnostic Italy was used. ELISA was done according to the manufactures instruction.

\subsection{Ethical Consideration}

The proposal was reviewed and approved by the Research and Ethical Committee of Baptist Medical Centre, Saki-Oyo state- Nigeria before the commencement of the work. Only subjects that volunteered themselves for the study were recruited.

\subsection{Data Analysis}

The result obtained was subjected to statistical analysis to determine mean, standard deviation, correlation coefficient and ' $t$ ' test at 0.05 level of significance using online: T-Test Calculator for 2 Dependent Means: www.socscistatistics.com/tests/ttestdependent/ A T-test calculator that compares 2 dependent population means for statistical significance.

\section{Results}

Table 1. TBA and virology markers in all studied groups

\begin{tabular}{|c|c|c|c|c|c|c|}
\hline & $\begin{array}{l}\text { Patients receiving treatment } \\
\text { in Orthodox hospitals }\end{array}$ & $\begin{array}{c}\text { Patients receiving } \\
\text { treatment in Herbal } \\
\text { homes }\end{array}$ & $\begin{array}{l}\text { Normal Control } \\
\text { Subjects }\end{array}$ & $P^{1}$ & $\boldsymbol{P}^{2}$ & $P^{3}$ \\
\hline $\mathbf{N}$ & 32 & 51 & 139 & & & \\
\hline $\begin{array}{c}\mathrm{TBA}(\mu \mathrm{mol} / \mathrm{L}) \\
\text { mean } \pm \mathrm{SD}\end{array}$ & $16 \pm 2.0$ & $18 \pm 3.2$ & $6.5 \pm 0.3$ & $0.258^{\mathrm{NS}}$ & $0.021^{\mathrm{s}}$ & $0.021^{\mathrm{S}}$ \\
\hline anti-HIV; N (\%) & $6.3 \%(2)$ & $7.8 \%(4)$ & $3.6 \%(5)$ & $0.0013^{\mathrm{S}}$ & $0.00003^{\mathrm{S}}$ & $0.000013^{\mathrm{S}}$ \\
\hline anti-HCV; N (\%) & $15.6 \%(5)$ & $17.6 \%(9)$ & $4.3 \%(6)$ & $0.14^{\mathrm{NS}}$ & $<\underset{S}{<0.00001}$ & $<\underset{S}{<0.00001}$ \\
\hline HBsAg; N (\%) & $25 \%(8)$ & $31.4 \%(16)$ & $7.2 \%(10)$ & $<\underset{\mathrm{S}}{<0.00001}$ & $<\underset{S}{<0.00001}$ & $<\underset{S}{<0.00001}$ \\
\hline $\begin{array}{c}\text { Anti-HIV + ANTI- } \\
\text { HCV }\end{array}$ & 0 & $2 \%(1)$ & 0 & $\underset{\mathrm{S}}{<0.00001}$ & - & $\underset{\mathrm{S}}{<0.00001}$ \\
\hline Anti-HIV + HBsAg & $3.1 \%(1)$ & $5.9 \%(3)$ & 0 & $0.003^{S}$ & $<0.00001^{\mathrm{S}}$ & $<\underset{\mathrm{S}}{<0.00001}$ \\
\hline Anti-HCV +HBsAg & 0 & 0 & 0 & - & - & - \\
\hline $\begin{array}{c}\text { Anti-HIV+Anti-HCV } \\
+ \text { HBsAg }\end{array}$ & 0 & 0 & 0 & - & - & - \\
\hline
\end{tabular}

$P^{1}$, TBA values in Patients receiving treatment in Orthodox hospitals / Patients receiving treatment in Herbal homes.

$P^{2}$, TBA values in Patients receiving treatment in Orthodox hospitals /Normal Control Subjects.

$P^{3}$, TBA values in Patients receiving treatment in Herbal homes / Normal Control Subjects.

S- Significant

NS- not significant

There was a lower prevalence of $6.3 \%(2) a n t-H I V$, $15.6 \%$ (5) anti-HCV and 25\%(8) HBsAg in patients receiving treatment from orthodox hospitals with a mean

plasma TBA of $16 \pm 2.0 \mu \mathrm{mol} / \mathrm{L}$ than the prevalence of the viral markers of $7.8 \%(4)$ ant-HIV, $17.6 \%(9)$ anti-HCV and $31.4 \%(16)$ HBsAg obtained in Patients receiving 
treatment in Herbal homes with a mean plasma TBA of $18 \pm 3.2 \mu \mathrm{mol} / \mathrm{L}$. There was also a lower viral markers of 3.6\%(5) anti-HIV, 4.3\%(6) anti-HCV and 7.2\%(10) HBsAg with a plasma TBA of $6.5 \pm 0.3 \mu \mathrm{mol} / \mathrm{L}$ in the normal control subjects than the results obtained from the patients receiving treatments from both orthodox and traditional/herbal homes (Table 1, Figure 1).

The immunochemical status revealed evidence of coinfections as $2 \%(1)$ anti-HIV + anti-HCV in patients receiving treatments in herbal homes, 3.1\%(1) anti-HIV + HBsAg in patients receiving treatments in orthodox hospitals with a mean plasma TBA of $16 \pm 2.0 \mu \mathrm{mol} / \mathrm{L}$ and $5.9 \%(3)$ anti-HIV + HBsAg in patients receiving treatments in herbal homes with a mean plasma TBA of $18 \pm 3.2 \mu \mathrm{mol} / \mathrm{L}$ (Table 1, Figure 1)..

There was no significant difference in the mean value of plasma TBA in patients receiving treatment in orthodox hospitals compared with the value of the parameter obtained in patients receiving treatments in herbal homes ( $>0.05)$. However there was a significantly higher difference in the mean plasma value of TBA obtained in the patients receiving treatment in orthodox hospitals and from the patients receiving treatments in herbal homes than the results obtained from the normal control with $\mathrm{p}<$ 0.05 (Table 1, Figure 1).

There was a higher significant value of the prevalence of anti-HIV in patients in herbal homes than the patients in orthodox hospital and control $(\mathrm{p}<0.05)$. A higher significant difference of anti-HIV was obtained in the patients in orthodox hospital than the control subjects $(\mathrm{p}<0.05)$ (Table 1, Figure 1$)$.

There was a no significant difference in the prevalence of anti-HCV in patients in herbal homes compared with the results obtained from the patients in orthodox hospital ( $>0.05)$. A higher significant difference of anti-HCV was obtained in the patients in orthodox hospital and herbal homes than the control subjects $(\mathrm{p}<0.05)$.

There was a higher significant value of the prevalence of HBsAg in patients in herbal homes than the patients in orthodox hospital and control $(\mathrm{p}<0.05)$. A higher significant difference of HBsAg was obtained in the patients in orthodox hospital than the control subjects $(\mathrm{p}<0.05)$ (Table 1 , Figure 1$)$.

There was a higher significant value of the prevalence of anti-HIV+ HBsAg in patients in herbal homes than the patients in orthodox hospital and control $(\mathrm{p}<0.05)$. A higher significant difference of anti-HIV+ HBsAg was obtained in the patients in orthodox hospital than the control subjects $(p<0.05)$. Anti-HIV + anti-HCV was found only in patients receiving treatment in herbal homes (Table 1, Figure 1).

Table 2. Frequency and Percentage of abnormally raised TBA in the test and control subjects

\begin{tabular}{|c|c|c|c|}
\hline & $\begin{array}{c}\text { Patients } \\
\text { receiving } \\
\text { treatment in } \\
\text { Orthodox } \\
\text { hospitals }\end{array}$ & $\begin{array}{c}\text { Patients } \\
\text { receiving } \\
\text { treatment in } \\
\text { Herbal homes }\end{array}$ & $\begin{array}{c}\text { Normal } \\
\text { Control } \\
\text { Subjects }\end{array}$ \\
\hline $\begin{array}{c}\text { Total number of } \\
\text { subjects recruited }\end{array}$ & 150 & 203 & 150 \\
\hline $\begin{array}{c}\text { Prevalence of } \\
\text { subjects with } \\
\text { abnormally } \\
\text { raised TBA }\end{array}$ & $32(21.3 \%)$ & $51(25.1 \%)$ & $11(7.3 \%)$ \\
\hline
\end{tabular}

Fifty one (51(25.1\%)) of 203 patients visiting herbal had abnormally raised Total Bile Acid, 32(21.3\%) out one hundred and fifty (150) patients visiting five (5) orthodox hospitals had abnormally raised TBA and 11(7.3\%) out of 150 apparently healthy individuals had abnormally raised plasma TBA (Table 2, Figure 1).

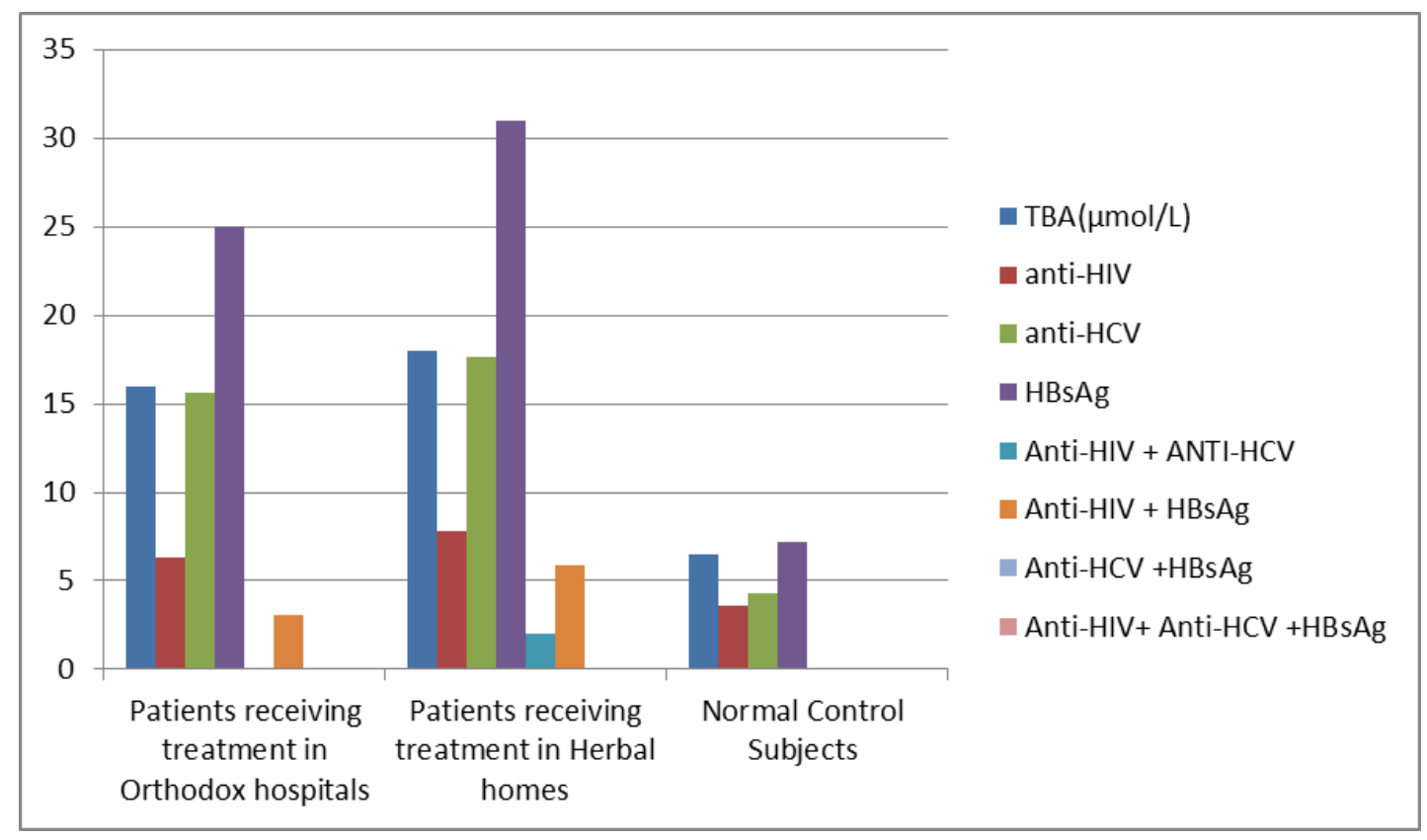

Figure 1. Pattern of viral markers and the Biochemical profiles of the test and the control subjects

\section{Discussion}

This work showed a lower prevalence of ant-HIV, antiHCV antibodies and HBsAg in patients receiving treatment from orthodox hospitals with a lower plasma
TBA than the prevalence of viral markers and the mean value of TBA obtained in patients receiving treatment in Herbal homes. This finding is attributable to the fact that Herbal Medical Practitioners only rely on the sign and symptoms as presented by the patients for treatment which may mask underline problems and infections which could 
also result in cross-infection in course of management ailments. In Nigeria, the majority of citizens with clinical conditions still use medicinal plants and visit traditional medicine practitioners for their health care needs. World Health Organization (WHO) have recognized the role of herbal traditional medicinal practice in primary health management due to the observation that $80 \%$ of the rural communities consult traditional healers before they go for the orthodox medical services. The traditional herbal practice remains familiar and attritional, thus least developed and hence the patients do not get the best values for their input in the services $[2,4]$.

In Nigeria, herbal and orthodox medicines are sometimes used interchangeably and concomitantly for treating same diseases. Hence, some attributes of the two types of medicines such as efficacy, safety and side effects in this case cannot be practically isolated and analyzed in order to arrive at objective deduction [10].

There was also a lower prevalence of positive anti-HIV, anti-HCV antibodies and HBsAg with a decreased plasma TBA in the normal control subjects than the results obtained from the patients receiving treatments from both orthodox and traditional/herbal homes. Patients attending orthodox settings and herbal homes to access treatments are clinical patients with health discomforts that could also be caused by viral infections which may be responsible for the immunochemical prevalence obtained in these subjects compare with the apparently healthy individuals without any clinical symptom of medical discomfort [7].

Liver enzymes AST, ALT ALP levels have been reported by Obi et al., [11] to be significantly higher in co-infection with hepatotropic viruses compared with mono-infection and control group under antiretroviral therapy. Otegbayo et al., [16] in south western Nigeria had similar result; Ballah et al.,[12] in the same environment and Ibeh et al., [13] in Eastern part of Nigeria.

However there was a significantly higher difference in the mean plasma value of TBA obtained in the patients receiving treatment in orthodox hospitals and from the patients receiving treatments in herbal homes than the results obtained from the normal control. Furthermore, Larger number of patients visiting herbal had abnormally raised total bile acid, than the patients visiting five (5) orthodox hospitals. The herbal preparation administered is always without a specific dosage which passes through the liver for metabolism. This could cause or complicate liver dysfunction as the baseline liver status is not always investigated hence the possibility of a raised plasma TBA compared to the more organized orthodox settings [4]. Hepatotoxicity and nephrotoxicity of plantextracts have been reported $[4,14,15]$ which could cause an abnormal increase in the plasma level of Total Bile acid.

There was a significantly higher difference in the mean plasma value of TBA and the prevalence of the viral markers including coinfection in the patients receiving treatment in orthodox hospitals and in the patients receiving treatments in herbal homes than the results obtained from the normal control. There was also a significantly higher prevalence of the viral markers including coinfection in the patients of herbal homes than the results obtained in the patients of orthodox hospitals and the normal control subjects. These findings could be attributed to the fact that clinically ill patients visit orthodox hospitals and herbal homes and are more likely to be positive to the viral markers and coinfection compared to the normal subjects. The herbal homes practioner may not maintain universal precautions aimed at preventing the transmission of the infectious diseases hence the higher prevalence of viral markers and the coinfection. This result is also consistent with the findings of Otegbayo et al., [16] Ballahetal., [12] that reported evidence of viral co-infection among the studied population in Nigeria.

\section{Conclusion and Recommendation}

The incidence of positive of HBsAg, anti-HIV, antiHCV antibodies increases with increase in Total Bile Acids and are more prevalent in patients receiving treatments from herbal homes than those attending orthodox hospitals with the evidence of HIV-HBV and HIV-HCV coinfection in the subjects with abnormally raised plasma TBA. The viral markers and the coinfection were found to be more prevalent in abnormally raised TBA in Herbal homes the those receiving treatments in Othordox hospital and normal control subjects. Furthermore, the viral markers including the coinfection were more prevalent in patients in herbal homes and orthodox hospital than the normal control subjects. There was no evidence of triple infection. Evaluation of Viral markers of patients with abnormally raised Total Bile Acid is recommended for effective management of this biochemical abnormality.

\section{References}

[1] Stanley, Bob. "Recognition and Respect for African Traditional Medicine". 2004: Canada's International Development Research Centre. Retrieved 11 March 2010.

[2] Job Isaac Jondiko Ogoche. Toward a clinical research framework for collaboration among selected stakeholders in traditional herbal medical practice in seme and gem sub-locations in Nyanza province, Kenya. : Vol. 8 (3), pp. 144-157, 17 January, 2014. Academic Journals http://www.academicjournals.org/JMPR

[3] Ekeanyanwu Chukwuma Raphael. Traditional Medicine in Nigeria: Current Status and the Future. Research Journal of Pharmacology, 5: 90-94. 2011.

[4] Odugbemi T. A. Textbook of Medicinal Plants from Nigeria: Lagos, University of Lagos Press. 2008

[5] Mokaila, Aone. "Traditional Vs. Western Medicine-African Context". Drury University, Springfield, Missouri 2001. Retrieved 11 March 2010.

[6] Helwig, David. "Traditional African medicine". 2010: Encyclopedia of Alternative Medicine. Retrieved 4 Feb 2010.

[7] Shaw-Stiffel T. A., "Chronic hepatitis," in Principles and Practice of Infectious Diseases, G. L. Mandell, J. E. Bennett, R. Dolin, et al., Eds., pp. 1297-1321, Churchill Livingstone, New York, NY, USA, 5th edition, 2000.

[8] Russell DW. "The enzymes, regulation, and genetics of bile acid synthesis". Annu. Rev. Biochem.: 72: 137-74. 2003. PMID 12543708.

[9] Chiang JY. "Bile acids: regulation of synthesis". J. Lipid Res.: 50 (10): 1955-66. 2009. PMC 2739756. PMID 19346330.

[10] K.P. Osemene, A.A. Elujoba and M.O. Ilori A Comparative Assessment of Herbal and Orthodox Medicines in Nigeria Research Journal of Medical Sciences: Volume 5 Issue 5, 280-285. 2011.

[11] Simon O. Obi, Haruna A. Baba, Marycelin M. Baba, Grace I. Amilo and Alhaji Bukar. The Effect of Co-infection of HIV and Hepatotropic Viruses on Selected Biochemical and Haematological Markers of Patients in Northeastern Nigeria. International Journal of Tropical Disease \& Health: 4 (5): 2014 SCIENCEDOMAIN international www.sciencedomain.org 
[12] Ballah AB, Ajayi B, Abja AU, Bukar AA, Akawu C, Ekong E. A survey of hepatitis $B$ and $C$ virus prevalence in HIV positive patients in a tertiary health institution in North Eastern Nigeria. International of Medicine and Medical Science.; 4 (1): 13-18.2012

[13] Ibeh BO, OluOmodamiro OD, Ibeh U and Habu JB. Biochemical and haematological changes in HIV subjects receiving Winnie cure antiretroviral drug in Nigeria. Journal of Biomedical Science.; 20: 73. 2013.

[14] Adeneye, A.A., Agbaje, E.O., Pharmacological evaluation of oral hypoglycemic and Antidiabetic effects of fresh leaves ethanol extract of Morinda lucida benth. in normal and alloxan-induced diabetic rats. Afr J. Biomed Res.,: 11: 65-71.2008
[15] Anofi, O.T.A., Olugbenga, O.O. Toxicological evaluation of Ethanolic root extract of Morinda lucida (L.) Benth (Rubiaceae) in male Wistar rats. J. Natural Pharmaceuticals,: 2 (2): 108-114. 2011

[16] Otegbayo JA1, Taiwo BO, Akingbola TS, Odaibo GN, Adedapo KS, Penugonda S, Adewole IF, Olaleye DO, Murphy R, Kanki P. Prevalence of hepatitis B and C seropositivity in a Nigerian cohort of HIV-infected patients. Ann Hepatol.: Apr-Jun; 7 (2): 152-6. 2008.

[17] Abbas, A., Lichtman, A., \&Pillai, S. Basic immunology Functions and Disorders of the Immune System. 2012; (4th ed., p. 40). Philadelphia, PA: Saunders/Elsevier. 